This item was submitted to Loughborough's Research Repository by the author.

Items in Figshare are protected by copyright, with all rights reserved, unless otherwise indicated.

\title{
Future use of life-cycle assessment in civil engineering
}

PLEASE CITE THE PUBLISHED VERSION

http://dx.doi.org/10.1680/coma.12.00037

PUBLISHER

(C) ICE Publishing

VERSION

VoR (Version of Record)

LICENCE

CC BY-NC-ND 4.0

REPOSITORY RECORD

Glass, Jacqueline, Tom Dyer, Costas Georgopoulos, Chris I. Goodier, Kevin Paine, Tony Parry, Henrikke Baumann, and Pernilla Gluch. 2019. "Future Use of Life-cycle Assessment in Civil Engineering". figshare. https://hdl.handle.net/2134/14053. 
This item was submitted to Loughborough's Institutional Repository (https://dspace.lboro.ac.uk/) by the author and is made available under the following Creative Commons Licence conditions.

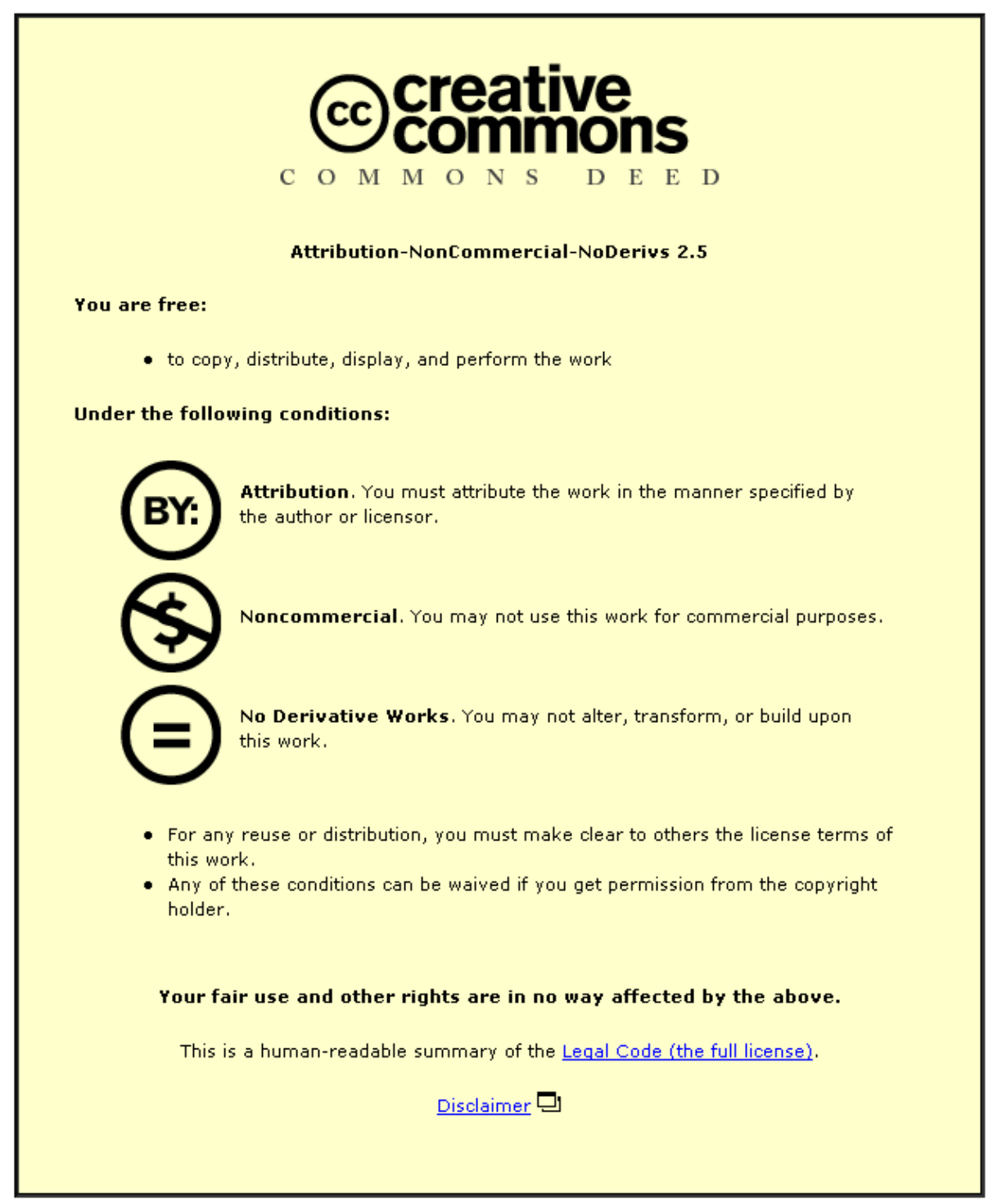

For the full text of this licence, please go to: http://creativecommons.org/licenses/by-nc-nd/2.5/ 


\section{Future use of life-cycle assessment in civil engineering}

1 Jacqueline Glass BA, DipArch, DipBRS, CertHE, PhD Professor of Architecture and Sustainable Construction, School of Civil and Building Engineering, Loughborough University, Loughborough, UK

2 Tom Dyer MSc, PhD

Lecturer, Concrete Technology Unit, Division of Civil Engineering, University of Dundee, Dundee, UK

3. Costas Georgopoulos MEng, MIGreekE, MSc, CEng, FHEA, FIStructE, FICE, FCS Professor, School of Civil Engineering, Kingston University, Kingston on Thames, Surrey, UK

4 Chris Goodier BEng, PhD, PGCert, MCIOB, MICT, FHEA Senior Lecturer in Materials and Structures, School of Civil and Building Engineering, Loughborough University, Loughborough, UK
5 Kevin Paine BEng, PhD

Senior Lecturer, Architecture and Civil Engineering, University of Bath, Bath, UK

6 Tony Parry MCIHT, PhD

Associate Professor, Nottingham Transportation Engineering Centre, University of Nottingham, Nottingham, UK

7 Henrikke Baumann MSc, PhD Associate Professor Energy and Environment Department, Chalmers University of Technology, Gothenburg, Sweden

8 Pernilla Gluch MSc, PhD

Associate Professor in Construction Management, Civil and Environmental Engineering Department, Chalmers University of Technology, Gothenburg, Sweden
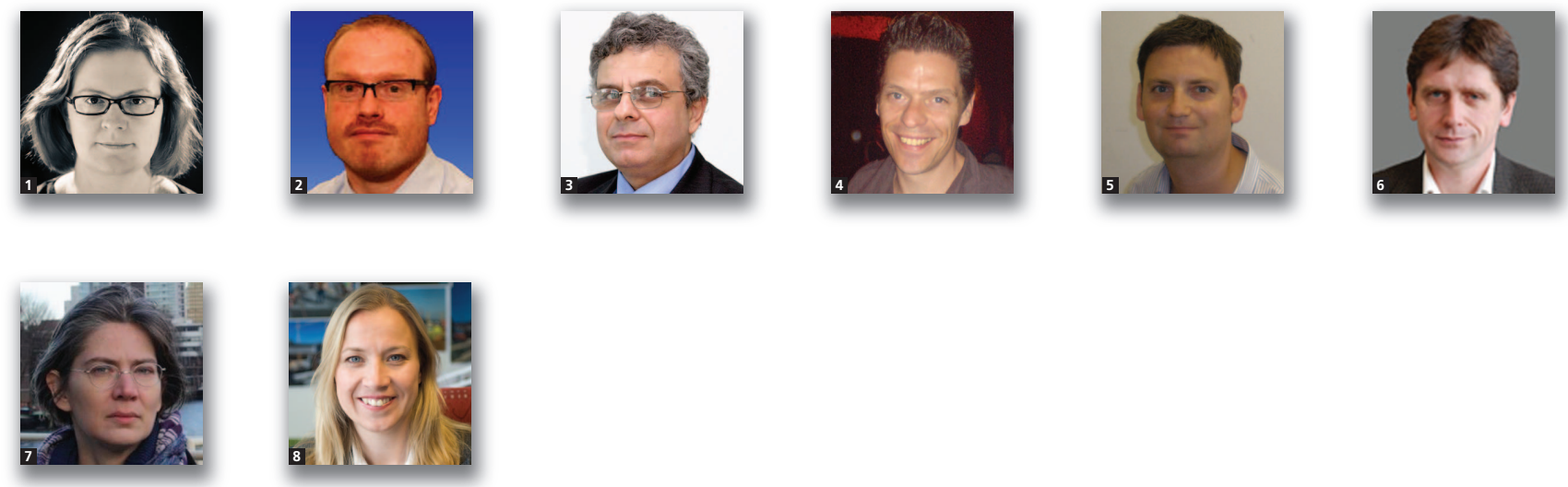

A LimesNet mission to Chalmers University of Technology, in Sweden, is reported in this paper. The aim of the mission was to explore new ways of exploiting the untapped potential of life-cycle assessment, its application in the civil engineering and construction industries and, specifically, to debate the associated trade-off decisions for reinforced concrete structures (buildings and civil engineering). Life-cycle assessment is an important tool in sustainable design; engineers need robust life-cycle assessment data and must balance this with operational performance considerations (e.g. energy consumption, durability). Through the mission it was clear that much could be learned from the Swedish experience. The UK team noted the importance of life-cycle assessment studies which allow building performance and construction products to be benchmarked and the role of emerging European standards (e.g. product category rules for construction and the development of environmental product declarations). Valuable lessons exist for consulting engineers and materials manufacturers, and there is a need for the greater inclusion of life-cycle assessment skills in the civil engineering education curriculum.

\section{Introduction: about the mission}

LimesNet (the network for low-impact materials and innovative engineering solutions for the built environment, an Engineering and Physical Sciences Research Council (EPSRC)-funded project, EP/J004219/1) aimed to create an international multidisciplinary community who share a common vision for the development and adoption of innovative low-impact materials and solutions in order to help deliver a more sustainable built environment. The aim of the LimesNet mission described in this paper was to convene a UK-Sweden workshop to explore new ways of tackling the problem of life-cycle assessment (LCA) and associated trade-off decisions for concrete structures in building and civil engineering. The UK-based authors visited Chalmers University of Technology, in Goteborg, Sweden on 22-23 
Construction Materials

Volume 166 Issue CM4
Future use of life-cycle

assessment in civil engineering

Glass, Dyer, Georgopoulos et al.
March 2012, where their visit was hosted by Dr Pernilla Gluch from the civil and environmental engineering department and Dr Henrikke Baumann (Baumann and Tillman, 2004), from the energy and environment department. The university has been a leader in the area of LCA since 1990 and hosts the Swedish LifeCycle Centre (see http://lifecyclecenter.se/); it has worked with major global companies such as ABB, Skanska and Volvo, and undertaken specific studies on packaging, pulp and paper, timber and construction materials. Although the focus was on LCA, a combination of presentations and discussions enabled the mission team and the host researchers to debate a wide range of related subjects, including conceptual design of sustainable buildings using concrete, using non-Portland cements in concrete construction, measuring raw material sustainability, product assessment and environmental product declarations (EPDs), responsible sourcing of construction products, longterm strategic planning and maintenance of UK infrastructure and carbon footprinting for road pavements. By the end of the mission it was clear that much could be learned from the Swedish LCA experts and there was significant opportunity for further collaboration to exchange knowledge and discuss developments in the UK. The UK team noted the importance of multi-company LCA studies that allow companies or products to be benchmarked and also raised the topical work of CEN TC/350, such as ISO 15804 (Product category rules for construction (BSI, 2012)) and the development of EPDs (BSI, 2010b, 2011b), discussed in detail in this paper. There was also a debate around assumptions used in LCA and how to predict the availability of materials in the future. This culminated in an interesting link being made between research on various scoring methods for the amount of natural resources in the world (Harrison et al., 2011) and the use of futures methods in the construction industry (Goodier et al., 2010) - such methods could be harnessed as part of a novel LCA methodology. A common theme was the apparent gap in the development of engineers' and construction professionals' skills in using LCA; it was felt that LCA was generally not included in the civil engineering curriculum in the UK. This is a genuine opportunity for civil engineering: LCA need not be the sole domain of environmental/energy specialists. There is a need to embed LCA in the curriculum such that the engineers of tomorrow are aware and prepared to use its results within the design process. Indeed, with civil engineers designing and building infrastructure with design lives of 30,100 or even 150 years, it is imperative that they at least possess a basic understanding of LCA principles, if not the skills to apply them directly.

\section{An industry in transition}

Construction and civil engineering as an industry creates highprofile structures, critical infrastructure and transport systems, yet has frequently been berated for its lack of forward thinking and poor performance, commercially, and for projects in which performance has been incommensurate with intended service lives (DTI, 2001; Fairclough, 2002; Foresight, 2008; Goodier et al., 2007). The industry is often perceived as lagging behind in adopting novel technologies, materials, practices and processes (Egan, 1998; Foresight, 2008; Goodier and Pan, 2010), yet designers are prevented from taking advantage of novel solutions (e.g. those with lower environmental impacts) because when these are developed, their journey into the marketplace and into specifications is slow and often tortuous. In contrast, conventional materials, codes and standards are based, in many cases, on more than 100 years of use and experience, such that there is confidence in their general behaviour. This principle remains true for innovation in respect of sustainability; while there may be a strong ethos to innovate to minimise environmental impacts, there may be a range of practical, regulatory or cultural challenges to doing so.

Requirements to minimise the carbon footprint of projects are increasingly recognised by some infrastructure clients. For example, the Environment Agency has committed to reduce carbon in everything it does, and share experiences with others (EA, 2010). An analysis of capital flood risk management schemes undertaken by the Environment Agency has shown that $25 \%$ of the carbon footprint associated with construction work relates to the use of concrete and more specifically Portland cement (Mason et al., 2011). Relative to its other ingredients, Portland cement (CEM I) has a high embodied environmental impact. There are two main environmental impacts associated with CEM I: depletion of abiotic resources - limestone, clay and other resources extracted for use as raw feed (Huntzinger and Eatmon, 2009); and carbon dioxide emissions from burning fuels in the rotary kiln and thermal decomposition of lime (Cembureau, 2006). Used with CEM I, materials such as fly ash and ground granulated blast-furnace slag (GGBS) can help, but there are also opportunities to reduce environmental impacts in other phases of the life cycle of a structure.

In 2011, the Environment Agency commissioned work to assess the embodied carbon dioxide $\left(\mathrm{eCO}_{2}\right)$ of concrete used in flood risk management infrastructure, with a view to assessing whether there was an opportunity to use alternative solutions and/or radical or novel materials to reduce the carbon footprint (Mason et al., 2011). A balanced assessment of durability for novel concretes (that use primarily non-Portland cement binders to reduce carbon emissions) proved too difficult to address, so the $\mathrm{eCO}_{2}$ of concrete was taken as the carbon dioxide emissions associated with production, manufacture, transport and installation of the material (i.e. the $\mathrm{eCO}_{2}$ at the point of use). The main source of data was the Environment Agency's construction carbon calculator (EACCC), an Excel spreadsheet-based tool that gives a list of $\mathrm{tCO}_{2} / \mathrm{t}$ for typical activities and materials used (EA, 2011). This was complemented by data for the $\mathrm{eCO}_{2}$ of the main 
Construction Materials

Volume 166 Issue CM4
Future use of life-cycle

assessment in civil engineering

Glass, Dyer, Georgopoulos et al. constituents of concrete as given in the University of Bath's inventory of carbon and energy (Hammond and Jones, 2011). Because the carbon dioxide produced during the maintenance and demolition of the structure could not be considered, it remains difficult, because of the long design life required, for industry to assess and use radical or novel materials which are untried. These considerations are particularly pertinent in critical design cases, such as flood risk management, where failure could be life threatening. There remains, therefore, a tension between the need for confidence in materials (Hewlett, 2011) and the need for more sustainable construction, with a radically lower impact (as well as a significantly lower carbon footprint, to comply with legally binding carbon targets).

This is likely to be amplified when other aspects of the full life cycle are considered (e.g. in building structures where operational (in-use) aspects are more significant than those of production). Indeed, research on embodied and operational carbon dioxide emissions of timber and masonry houses (Arup, 2006) has concluded that the difference in $\mathrm{eCO}_{2}$ for timber frame and concrete masonry construction is $4 \%$ for a typical house, which can be offset in 11 years when thermal mass is exploited; whole life carbon dioxide emissions for concrete masonry construction are significantly lower than timber, ranging from $7 \%$ to $17 \%$ when thermal mass is exploited.

These examples show that assessment of the environmental impacts of materials in the civil engineering context is complex, but it is important to be able to broaden out beyond key indicators (such as carbon and waste) to include climate change, ozone depletion, acidification of land and water, eutrophication, material depletion and waste production. These are all typically included in LCA studies, as discussed next.

\section{The status of LCA}

Life-cycle assessment is 'the process of evaluating the effects that a product has on the environment over the entire period of its life cycle...extraction and processing; manufacture; transport and distribution; use, re-use and maintenance; recycling and final disposal' (UNEP, 1996). It is used to inform decisions on material selection to better understand, measure and reduce environmental impacts, hence it is sometimes referred to as environmental LCA. LCA procedures are harmonised in ISO14040:2010 and ISO14044:2010 (BSI, 2006a, 2006b), and a growing number of published LCA studies now exists in the civil and structural engineering domain. Although not an exhaustive list, such studies include

- studies of civil engineering infrastructure (e.g. Santero et al. (2011a), focusing on a comparison of concrete and asphalt pavement for highway construction; Huang et al. (2012), which explores the challenges around undertaking LCA for pavement construction, specifically in terms of the sensitivity of different assumptions within the methodology)

building structures (e.g. Ochsendorf et al. (2011) in which an LCA is developed for concrete and timber residential properties in different areas of the USA to explore the relationship between embodied and operational energy of these typical construction approaches)

construction products (e.g. Gäbel and Tillman (2005), which covers environmental impacts in cement production, but many LCA studies have also been published by individual material suppliers/manufacturers).

However, LCA studies can sometimes be influenced by vested interest, incomplete life cycles, and a lack of rigour and disclosure of methodological choices; there are anecdotal reports of some LCA reports being suppressed because the results were somewhat unexpected. Importantly, methodological choices depend on the purpose of the study, but people may not agree on the purpose of a study and the objectives and assumptions may not always be well explained. As a result, there can be a lack of transparency in and comparability between LCA results. The ISO standards do not prescribe methodological choices, so that individual studies may adopt those most appropriate to their domain. This leaves the challenge for any industry or material sector to agree and adopt one or more sets of standard approaches (Santero et al., 2011b) in order to provide transparent and comparable LCA results. This is necessary, both to promote the science of LCA in the domain, but also to provide designers, who are not usually LCA experts, with the information necessary to estimate the environmental impacts of design choices. Hence, there is little discussion and no agreement between practitioners on the effects of different LCA methods (e.g. inventory, definitions of use phase, allocation to by-products or end-of-life scenarios).

The use of LCA results by practising engineers is currently very limited and previous studies have identified a strong need to include LCA education (among other things) in engineering curricula to prepare students for sustainability challenges and transition (e.g. Allenby, 2007; Dwyer and Byrne, 2010; Gutierrez-Martin and Hüttenhain, 2003). Recent UK guidance on the embodied impacts of construction products is helpful (Anderson and Thornback, 2012) and in education, the university of Dundee includes a full module on LCA in its masters programme for civil engineering; the students appear to adapt well to the systematic nature of LCA. However, these initiatives on their own are not sufficient to meet the full needs of the design and asset management community.

An intervention could be made at policy level, underpinned by government organisations such as the Technology Strategy Board, whose resource efficiency strategy aim states: 'we believe the UK should support the wider adoption of life-cycle 
Construction Materials

Volume 166 Issue CM4
Future use of life-cycle

assessment in civil engineering

Glass, Dyer, Georgopoulos et al. thinking through the use of indicators and quantitative methods, such as life-cycle assessment, embedded carbon and embedded water' (Technology Strategy Board, 2009, p. 33). Recent research has also concluded that public databases of LCA studies, more research on life-cycle costing of environmental impacts (Ochsendorf et al., 2011), standardised frameworks for LCA (Santero et al., 2011b) and research to address the issue of complexity in LCA (Zamagni et al., 2012) are needed urgently.

\section{Counting materials in LCA}

Resource efficiency is an example of the crucial components of sustainable development and strategic priorities for policy and research (European Commission, 2011; UK government, 2011; WRAP, 2010). Consequently, when measuring the environmental impact of a project, the use of raw materials is an essential part of this; but it is also often a sector-specific challenge. Consumption of raw materials forms part of the environmental impact of a civil engineering project, for which 'total material requirement' (TMR) and 'abiotic depletion potential' (ADP) are the current favoured approaches in measurement terms. TMR is a measure of the total mass of raw materials required to produce the finished product (BRE, 2007). Although the data required for calculation are usually readily available, TMR is compromised by its inability to distinguish between scarce and abundant material (any measure of resource efficiency should ideally take into account the proximity to exhaustion of a given resource), whereas ADP achieves this by incorporating terms for the reserve base and rate of extraction of a given resource within it (Adriaanse et al., 1997; Van Oers et al., 2002). However, more detailed analysis of ADP indicates that scarcity is not well represented by the indicator - the emphasis is placed on the size of the reserve base, which is not a good measure of scarcity because it overlooks factors such as accessibility. Harrison et al. (2011) have developed an indicator as an attempt to better reflect resource scarcity, the 'current scarcity score' (CSS). Along with abiotic resources, which are normally represented by such metrics, the indicator incorporates biotic resources, water use and the findings of the EU raw materials initiative (RMI) (Raw Materials Supply Group, 2010). Yet this indicator finds itself excluded from LCA applications conducted in accordance with ISO 14044 (BSI, 2006), owing to its use of weighting factors and debate on whether sufficient data are available to permit biotic resources to be incorporated in a meaningful way. The challenge of developing a version that is wholly compatible is therefore an attractive one.

Nevertheless, if it is accepted that, despite some clear shortcomings that need to be tackled, LCA is a robust tool and, therefore, potentially helpful in civil engineering and construction decision making, then there is still a problem with scope - LCA only considers environmental issues. The true 'cost' of winning resources and undertaking projects would surely also take social and societal factors into account (such as labour rights, community impact and engagement), hence addressing issues of social responsibility (BSI, 2010a). Efforts have been made in the LCA community to include social and economic dimensions into life-cycle modelling (e.g. Baumann et al., 2012; Gluch and Baumann, 2004; Steen, 2005), but the many dimensions of sustainability have yet to be merged into a coherent life-cycle modelling framework (although the International Society for Industrial Ecology has provided a platform for exchange and meetings on life-cycle sustainability assessment since 2011, see http://www.is4ie.org/).

Currently, Skaar and Fet (2011) contend that integrated reporting of economic, social and environmental aspects exists only at the level of 'the corporation', calling for methods that include both the extended supply chain and the product life cycle. One pathway is provided by BS 8905 (BSI, 2011a), which provides a framework for the sustainable use of materials (by including a range of parameters, alongside LCA-type data). There are fundamental problems in introducing such an approach in construction, however, such as the industry's piecemeal understanding of the social and ethical dimensions of business (Murray and Dainty, 2009), differences in project participants' values towards sustainability (Fellows and Liu, 2008) and the widely acknowledged complexity of assessing sustainability performance more holistically (Cole, 1998, 1999; Haapio and Viitaniemi, 2008). This discussion relates closely to the emergent subject of 'responsible sourcing' (Glass, 2011). Although there is no single definition for responsible sourcing, it refers to a standardised approach to the management of sustainability issues associated with materials in the construction supply chain, usually as a means to procure materials with a certified provenance (BRE, 2009; BSI, 2009). Glass et al. (2012) note that this is a complex issue, which requires the involvement of manufacturers, clients, contractors and designers, but they argue that such an approach provides the social, ethical and moral narrative that LCA arguably omits.

\section{Embedding LCA in established assessment schemes}

In the UK, the BRE's 'Ecopoint' system (Dickie and Howard, 2000; Howard et al., 1999) utilises an LCA approach similar to that required for EPDs. In this example, credits are awarded in BREEAM (the Building Research Establishment environmental assessment method), based on the Green Guide to Specification (Anderson et al., 2009), for a number of building elements (such as external and internal walls, roof, upper floor slabs). The Ecopoint system is not 100\% compliant with ISO 14040 (BSI, 2006a); it is based on a single, weighted point score and 'Ecopoint' values for individual materials are not publicised. As a result, the scheme's value for design development is somewhat limited at this time. Other rating schemes such as 'Leadership in 
Construction Materials

Volume 166 Issue CM4
Future use of life-cycle

assessment in civil engineering

Glass, Dyer, Georgopoulos et al. energy and environmental design' (Leed) that do not currently have LCA credits are in the process of developing them (see http://www.leeduser.com/credit/Pilot-Credits/PC1). In the forthcoming version of 'Ceequal', the civil engineering environmental assessment awards scheme (see www.ceequal.com), there will be two mandatory questions on LCA, but teams are also asked about LCA in the context of the contribution of the project towards the achievement of a more sustainable society. This update to Ceequal provides a strong indication that expectations are set to change in sustainability terms, not least because requirements to minimise environmental footprint are increasingly recognised by clients and asset owners.

The main challenge of embedding LCA in green building rating schemes is to develop the methodology and benchmarks needed to embed LCA effectively and legitimately in such schemes (Ove Arup, 2012), but the use of LCA is in fact much more diverse than scheme-related LCA. Although the schemes are important, the use of LCA for strategic learning in industry and for research should not be forgotten. One study on corporate use of LCA has shown that it was used mainly for organisational learning (Baumann, 1998; Frankl and Rubik, 2000), such as identification of organisational location for environmental risks or development of new, in-house ecodesign rules. Despite these advantages, for both practical and historical reasons, expertise in LCA often remains concentrated within disciplines that generally lie outside the civil engineering community. Most LCA studies are carried out by expert practitioners using dedicated software packages (such as SimaPro or Pems), so it is a specialist field within environmental systems analysis. Moreover, professionals, as well as lay-people, can struggle to understand and interpret LCA output information (Steen et al., 2008), which is increasingly being published by way of EPDs (BSI, 2010b, 2011b). EPDs are governed by product category rules (PCR), a 'set of specific rules, requirements and guidelines' for developing EPDs for a particular product or group of products (BRE, 2007) to ensure completeness, consistency and comparability, yet the proliferation of PCRs that go beyond the strict remit of EPDs has caused problems; programme operators around the world use different approaches, and so outputs are not comparable (Schminke and Grahl, 2007). With more than 40000 commodity categories, there is a need to maintain a high level of transparency and collaboration, transcend geographical standards-making, encourage greater stakeholder involvement and, importantly, avoid the development of conflicting PCRs (Ingwersen and Stevenson, 2012). Consensus-built frameworks can help promote the science of LCA and provide designers, who are not usually LCA experts, with information to estimate the environmental impacts of design choices, with the caveat that users may still not 'make the effort' to interpret it (Steen et al., 2008). To help address this, the new PCR for construction (BSI, 2012) requires information on typical environmental (but not social or any other) impacts to be presented in a consistent manner (BSI, 2011b). It does account for the relative scarcity of a material, but so-called after-life attributes such as recyclability and recarbonation are not permissible and the re-allocation of impacts onto low-value by-products such as fly ash or scrap is not allowed. That said, Strazza et al. (2010) suggest there is growing interest in product (manufacturer)-specific EPDs and also product (generic)-type EPDs, citing the example of generic EPD development in the Italian cement sector. They also acknowledge that evaluation of a building product such as cement without account of its full life cycle would be 'nonsense', and in so doing recognise that a trans-business or trans-sector approach is critical to producing an EPD that truly represents a product's application space.

\section{Future prospects}

So, where does this leave us? Even if LCA data, plus accompanying user tools and the skills to apply them, were available, there is a problem of forecasting what characteristics the future might actually hold for any given project. An understanding and appreciation of the future should arguably be a fundamental requirement in this sector because the civil engineering supply chain designs, builds and increasingly manages and operates civil infrastructure and structures that will be used over many decades, with the design life of major infrastructure often being 100 or even 150 years. The civil engineering community needs to expand its planning horizons to prepare for potential future events, trends and operating environments (Foresight, 2008; Goodier and Pan, 2010; Harty et al., 2007), yet construction companies appear reluctant to engage in planning beyond a few years, or past the next project, and there is little evidence of a formal process in the formulation of long-term strategies. (Basic strategic planning is conducted, but the process relies on SWOT (strengths, weaknesses, opportunities and threats) or PESTEL (political, economic, social, technological, environmental and legal)/Steep type analyses (Betts and Ofori, 1992; Brightman et al., 1999; Goodier et al., 2010; Price, 2003) and focuses more on company business or market strategy rather than structure or infrastructure.) Some examples exist, in the form of future scenarios for a place, a technology or a sector (e.g. Foresight, 2006; Goodier and Pan, 2010), but are rarely used to inform company or design strategy. This contrasts with other sectors that routinely use scenario planning and other future techniques to help shape their long-range planning (Eden and Ackermann, 1998; Hiemstra, 2006). The marked reluctance in construction to plan for the long term is said to be due to the relative volatility of the market and a perceived lack of control over factors external to the organisation (Goodier et al., 2010), but this is stifling the development of future-focused design and construction approaches.

There is much to gain, however; Kaethner and Burridge (2012) suggest that, on a typically sized non-domestic building, 
Construction Materials

Volume 166 Issue CM4
Future use of life-cycle

assessment in civil engineering

Glass, Dyer, Georgopoulos et al. through careful specification, a structural engineer could save their lifetime's personal carbon footprint. Yet a cultural change to embed and enact this idea in everyday practice can take time. In Sweden, a regular survey of the construction industry's environmental attitudes and practices has shown that it takes at least 10 years for companies to go from awareness about sustainability issues to having an array of sustainability practices implemented in their business (Thuvander et al., 2011). The survey noted that evidence of life-cycle thinking is found mainly in materials databases, procurement procedures and as a decision-making parameter for source separation and other waste management practices.

One particular opportunity, pertaining to sustainability, is to combine the science of futures-based research with quantitative analysis mechanisms within LCA to explore possible futures in a more numerical way, which might work more effectively than purely qualitative approaches. Certainly there is scope for new models and tools in this area. It is pertinent that the aforementioned study for the Environment Agency (Mason et al., 2011) attempted to provide infrastructure engineers with data on cements, precast concrete, cladding, local aggregates and reinforcement steel. They concentrated on limiting cradleto-gate effects, but end-of-life issues and a balanced assessment of durability proved too difficult to address (despite its obvious importance), so there is another interesting opportunity there, notwithstanding underlying concerns about the veracity of the concept of future forecasting, as noted by authors such as Gardner (2010). Alternatively, Trinius and Sjostrom (2007) propose a modular approach to understand environmental issues through the life cycle of a product or building, based on the developing international standards in the area. They contend that such standards need to be integrated into business models that are applied in the sector and call for more meaningful use of quantifiable data, for example within EPDs. However, 5 years after their paper was published, very few EPDs exist for construction materials and sectors have only recently begun to mobilise themselves to address this fundamental gap. Furthermore, Zamagni et al. (2012) acknowledge the tension between the need for greater fidelity and the need for better usability of LCA; they suggest that knowledge needs to be made available with 'tolerable uncertainty'.

\section{Conclusion}

There is clearly a set of challenges currently constraining the development and application of LCA in civil engineering projects and practices. The result is that engineers' ability to create low-impact buildings and sustainable infrastructure is being hindered. LCA is an important tool in sustainable design; engineers need robust LCA data and hence need to balance this with other performance considerations. However, most UK civil engineering and construction courses do not prepare engineers to interpret/employ LCA within decision making, so there is currently a skills and knowledge gap. The LimesNet mission found that Chalmers University of Technology in Sweden had

a systematic approach to the education of all engineers on LCA techniques, regardless of discipline background

- a close interaction with industry to commission LCA studies and industry deployed the results directly into the production environment

a strengthening research community around LCA and lifecycle management.

The UK authors of this paper intend to pursue a number of novel research and educational trajectories that have emerged from this mission, including ideas for developments within metrics, tools, implementation and education associated with LCA.

\section{Acknowledgements}

The authors would like to thank the Engineering and Physical Sciences Research Council (EPSRC) and the University of Bath (which led the LimesNet project for EPSRC), for supporting the 'Responsible Choices' international mission to Sweden. The UK-based authors would like to thank Dr Baumann and Dr Gluch for hosting the international mission and giving so generously of their time, expertise and enthusiasm.

\section{REFERENCES}

Adriaanse A, Bringezu S, Hammond A et al. (1997) Resource Flows: The Material Basis of Industrial Economies. World Resources Institute, Washington, DC, USA.

Allenby B (2007) Sustainable engineering education: translating myth to mechanism. Proceedings of the 2007 IEEE International Symposium on Electronics and the Environment, pp. 52-56, http://dx.doi.org/10.1109/ISEE. 2007.369366.

Anderson J and Thornback J (2012) A Guide to Understanding the Embodied Impacts of Construction Materials. Construction Products Association, London, UK.

Anderson J, Shiers D and Steele K (2009) The Green Guide to Specification, an Environmental Profiling System for Building Materials and Components. Building Research Establishment (BRE), Watford, UK.

Arup (2006) Whole Life Performance Research: a Lifecycle Analysis of Carbon Dioxide Emissions from Housing under Climate Change Examining the Role of Thermal Mass. Arup Research and Development, London, UK.

Baumann B (1998) Life Cycle Assessment and Decision Making: Theories and Practices. PhD dissertation, Chalmers University of Technology, Göteborg, Sweden.

Baumann H and Tillman A-M (2004) The Hitch-Hiker's Guide to LCA: an Orientation in Life Cycle Assessment Methodology 
Future use of life-cycle

assessment in civil engineering

Glass, Dyer, Georgopoulos et al. and Applications. Studentlitteratur AB, Chalmers

University, Göteborg, Sweden.

Baumann H, Arvidsson R, Tong H and Wang Y (2012) Does the production of an airbag injure more people than the airbag saves in traffic? Opting for an empirically-based approach to S-LCA methodology. Journal of Industrial Ecology in press.

Betts M and Ofori G (1992) Strategic planning for competitive advantage in construction. Construction Management and Economics 10(6): 511-532.

BRE (Building Research Establishment) (2007) Methodology for Environmental Profiles of Construction Products: Product Category Rules for Type III Environmental Product Declaration of Construction Products (DRAFT). BRE, Watford, UK.

BRE (2009) BES 6001: Issue 2.0 Framework Standard for the Responsible Sourcing of Construction Products. BRE, Watford, UK.

Brightman JR, Eden C, van der Heijden K and Langford DA (1999) The development of the construction alternative futures explorer. Automation in Construction 8(6): 613-623.

BSI (2006a) BS EN ISO 14040:2006: Environmental management - Life cycle assessment - Principles and framework. BSI, London, UK.

BSI (2006b) BS EN ISO 14044:2006: Environmental management - Life cycle assessment - Requirements and guidelines. BSI, London, UK.

BSI (2009) BS 8902:2009: Responsible sourcing sector certification schemes for construction products Specification. BSI, London, UK.

BSI (2010a) BS ISO 26000:2010: Guidance on social responsibility. BSI, London, UK.

BSI (2010b) PD CEN/TR 15941:2010: Sustainability of construction works - Environmental product declarations - Methodology for selection and use of generic data. BSI, London, UK.

BSI (2011a) BS 8905:2011: Framework for the assessment of the sustainable use of materials - guidance. BSI, London, UK.

BSI (2011b) BS EN ISO 15942: 2011: Sustainability of construction works - Environmental product declarations Communication format business-to-business. BSI, London, UK.

BSI (2012) BS EN ISO 15804: 2012: Sustainability of construction works - Environmental product declarations - Product category rules. BSI, London, UK.

Cembureau (2006) LCA Study Data. European Platform on LCA, Brussels, Belgium. See http://lca.jrc.ec.europa.eu/ lcainfohub/dataset2.vm?id=105 (accessed 25/08/2012).

Cole R (1998) Emerging trends in building environmental assessment methods. Building Research and Information 26(1): 3-16.

Cole R (1999) Building environmental assessment methods: clarifying intentions. Building Research and Information 27(4-5): 230-246.

Dickie I and Howard N (2000) BRE Digest 446 - Assessing Environmental Impacts of Construction. BRE, Watford, UK.

DTI (Department of Trade and Industry) (2001) Constructing the Future: Foresight Report. Built Environment and Transport Panel, Construction Associate Programme, Department of Trade and Industry, London, UK.

Dwyer B and Byrne EP (2010) Practical skills and techniques for the transition to a sustainable future, a case study for engineering education. Proceedings of the 3rd International Symposium for Engineering Education ISEE2010, University College Cork, Ireland. See http://www.ucc.ie/ academic/processeng/isee2010/index.htm (accessed 03/05/ 2013).

EA (Environment Agency) (2010) Creating a Better Place 2010 2015: Our Corporate Strategy. Environment Agency, London, UK. See http://publications.environment-agency. gov.uk/PDF/GEHO1109BQXE-E-E.pdf (accessed 25/08/ 2012).

EA (2011) Carbon Calculator for Construction Activities. Environment Agency, London, UK. See http://www. environment-agency.gov.uk/static/documents/Business/ Carbon_calculator_v3_1_2.xls (accessed 25/08/2012).

Eden C and Ackermann F (1998) Making Strategy: the Journey of Strategic Management. SAGE Publications, London, UK.

Egan J (1998) Rethinking Construction. HMSO, London, UK. European Commission (2011) Communication from the Commission to the European Parliament, the Council, the European Economic and Social Committee and the Committee of the Regions: A Resource-efficient EuropeFlagship Initiative under the Europe 2020 Strategy. COM (2011) 21, Brussels, Belgium.

Fairclough J (2002) Rethinking Construction Innovation and Research: A Review of Government R\&D Policies and Practices. Department of Transport, Local Government and the Regions, London, UK.

Fellows R and Liu AMM (2008) Impact of participants values' on construction sustainability. Proceedings of the Institution of Civil Engineers - Engineering Sustainability 161(4): 219-227.

Foresight (2006) Foresight: Intelligent Infrastructure Futures. Office of Science and Technology, DTI, London, UK.

Foresight (2008) Sustainable Energy Management and the Built Environment, Final Report. The Government Office for Science, London, UK.

Frankl P and Rubik F (eds) (2000) Life Cycle Assessment in Industry and Business: Adoption Patterns, Applications and Implications. Springer Verlag, Berlin, Germany.

Gäbel K and Tillman A-M (2005) Simulating operational alternatives for future cement production. Journal of Cleaner Production 13(13-14): 1246-1257. 
Construction Materials

Volume 166 Issue CM4
Future use of life-cycle

assessment in civil engineering

Glass, Dyer, Georgopoulos et al.
Gardner D (2010) Future Babble: Why Expert Predictions Fail And Why We Believe Them Anyway. McClelland and Stewart, Toronto, Canada.

Glass J (2011) Briefing: Responsible sourcing of construction products. Proceedings of the Institution of Civil Engineers Engineering Sustainability 164(3): 164-165.

Glass J, Achour N, Parry T and Nicholson I (2012) Engaging small firms in sustainable supply chains: responsible sourcing practices in the UK construction industry. International Journal of Agile Systems and Management 5(1): 29-58.

Gluch P and Baumann H (2004) The life cycle costing (LCC) approach: a conceptual discussion of its usefulness for environmental decision-making. Building and Environment 39(5): $571-580$.

Goodier Cl and Pan W (2010) The Future of UK Housebuilding. RICS, London, UK. See http://www.rics.org/Global/Downloads/ RICS_Research_The_Future_of_UK_Housebuilding.pdf (accessed 11/02/2013).

Goodier Cl, Soetanto R, Dainty ARJ et al. (2007) A competitive future for UK construction? Construction Information Quarterly 9(4): 169-174.

Goodier Cl, Austin SA, Soetanto R and Dainty ARJ (2010) Causal mapping and scenario building with multiple organisations. Futures: the Journal of Policy, Planning and Futures Studies 42(3): 219-229.

Gutierrez-Martin F and Hüttenhain SH (2003) Environmental education: new paradigms and engineering syllabus. Journal of Cleaner Production 11(3): 247-251.

Haapio A and Viitaniemi P (2008) A critical review of building environmental assessment tools. Environmental Impact Assessment Review 28(7): 469-482.

Hammond G and Jones C (2011) Inventory of Carbon and Energy (ICE) Version 2.0. University of Bath, Bath, UK.

Harrison TA, Jones R, Dyer T and Halliday J (2011) Sustainable Use of Natural Resource Project - Phase 2 A Report, University of Dundee, Dundee, UK. See http://www.snrproject.org (accessed 25/08/2012).

Harty C, Goodier Cl, Soetanto R et al. (2007) The futures of construction: a critical review of construction futures studies. Construction Management and Economics 25(5): 477-493.

Hewlett P (2011) Assessing risk associated with products. Magazine of Concrete Research 63(8): 551-552.

Hiemstra G (2006) Turning the Future into Revenue. John Wiley, Hoboken, NJ, USA.

Howard N, Edwards S and Anderson J (1999) Methodology for Environmental Profiles of Construction Materials, Components and Buildings. BRE, Watford, UK.

Huang Y, Spray A and Parry T (2013) Sensitivity analysis of methodological choices in road pavement LCA. International Journal of Life Cycle Assessment 18(1): 93 101.
Huntzinger DN and Eatmon TD (2009) Life-cycle assessment of Portland cement manufacturing: comparing the traditional process with alternative technologies. Journal of Cleaner Production 17(7): 668-675.

Ingwersen WW and Stevenson M (2012) Can we compare the environmental performance of this product to that one? An update on the development of product category rules and future challenges toward alignment. Journal of Cleaner Production 24(3): 102-108.

Kaethner SC and Burridge JA (2012) Embodied $\mathrm{CO}_{2}$ of structural frames. The Structural Engineer May: 33-40.

Mason J, Paine KA and Rogers K (2011) Low Carbon Concrete. Guidelines for Reducing the Carbon Footprint of Concrete Used in Flood Risk Management Infrastructure. Black and Veatch Report to the Environment Agency, London, UK.

Murray M and Dainty ARJ (eds) (2009) Corporate Social Responsibility in the Construction Industry. Taylor \& Francis, Abingdon, UK.

Ochsendorf J, Norford LK, Brown D et al. (2011) Methods, Impacts and Opportunities in the Concrete Building Life-cycle. Concrete Sustainability Hub, MIT, Cambridge, MA, USA.

Ove Arup (2012) The Value of Structural Engineering to Sustainable Construction: Final Report. Ove Arup and Partners, London, UK.

Price ADF (2003) The strategy process within large construction organisations. Engineering, Construction and Architectural Management 10(4): 283-296.

Raw Materials Supply Group (2010) Critical Raw Materials for the EU-Report of the Ad-Hoc Group on Defining Critical Raw Materials. European Commission, Enterprise and Industry, Brussels, Belgium. See http://ec.europa.eu/ enterprise/policies/raw-materials/documents (accessed 25/ 08/2012).

Santero N, Loijos A, Akbarian M and Ochsendorf J (2011a) Methods, Impacts and Opportunities in the Concrete Pavement Life-Cycle. Concrete Sustainability Hub, MIT, Cambridge, MA, USA.

Santero N, Masanet E and Horvarth A (2011b) Life cycle assessment of pavements. Part I: critical review. Resources, Conservation and Recycling 55(9-10): 801-809.

Schminke E and Grahl B (2007) The part of LCA in ISO Type III environmental declarations. International Journal of Life Cycle Assessment 12(1): 38-45.

Skaar C and Fet AM (2011) Accountability in the value chain: from environmental product declaration (EPD) to CSR product declaration. Corporate Social Responsibility and Environmental Management 19(4): 228-239.

Steen B (2005) Environmental costs and benefits in life cycle costing. Management of Environmental Quality: An International Journal 16(2): 107-118.

Steen B, Garling A, Imrell AM and Sanne K (2008) Development of interpretation keys for environmental product declarations. Journal of Cleaner Production 16(5): 598-604. 
Strazza C, Del Borghi A, Blengini GA and Gallo M (2010)

Definition of the methodology for a sector EPD (environmental product declaration): case study of the average Italian cement. International Journal of Life Cycle Assessment 15(6): 540-548.

Technology Strategy Board (2009) Resource Efficiency Strategy 2009-2012. Technology Strategy Board, Swindon, UK.

Thuvander L, Gluch P, Gustafsson M and Baumann H (2011) Twelve years of environmental work in the Swedish construction industry. Proceedings of the International Sustainable Building Conference SB11, Helsinki, Finland.

Trinius W and Sjostrom C (2007) Sustainability in building construction - international standards in progress. Journal of ASTM International 4(7), http://dx.doi.org/10.1520/ JAI101101.

UK government (2011) Europe 2020 Strategy: Roadmap to a Resource Efficient Europe, Non-paper by the United Kingdom. Department for Environment, Food and Rural Affairs, London, UK. See http://www.defra.gov.uk/ publications/files/resource-efficient-europe.pdf (accessed 25/08/2012).

UNEP (United Nations Environment Programme) (1996) Life-Cycle Assessment: What It Is and How to Do It. UNEP, New York, NY, USA.

Van Oers L, De Koning A, Guinee JB and Huppes G (2002) Abiotic Resource Depletion in LCA: Improving Characterisation Factors for Abiotic Resource Depletion. Road and Hydraulic Engineering Institute, Dutch Ministry of Transport, Public Works and Water Management, Amsterdam, the Netherlands.

WRAP (2010) Securing the Future - the Role of Resource Efficiency. WRAP, Banbury, UK. See http://www.wrap. org.uk/sites/files/wrap/FULL\%20REPORT\%20v2.pdf (accessed 17/08/2012).

Zamagni A, Masoni P, Buttol P, Raggi A and Buonamici R (2012) Finding life cycle assessment research direction with the aid of meta-analysis. Journal of Industrial Ecology 16(S1): S39S52.

\section{WHAT DO YOU THINK?}

To discuss this paper, please email up to 500 words to the editor at journals@ice.org.uk. Your contribution will be forwarded to the author(s) for a reply and, if considered appropriate by the editorial panel, will be published as discussion in a future issue of the journal.

Proceedings journals rely entirely on contributions sent in by civil engineering professionals, academics and students. Papers should be 2000-5000 words long (briefing papers should be 1000-2000 words long), with adequate illustrations and references. You can submit your paper online via www.icevirtuallibrary.com/content/journals, where you will also find detailed author guidelines. 